\title{
Ursolic Acid Reduces the Metalloprotease/Anti-Metalloprotease Imbalance in Cerebral Ischemia and Reperfusion Injury [Corrigendum]
}

Wang Y, He Z, Deng S. Drug Des Devel Ther. 2016;10:1663-1674.

The authors have advised due to an error at the time of figure assembly, Figure 4A on page 1670 is incorrect. The correct Figure 4 is shown below.

A
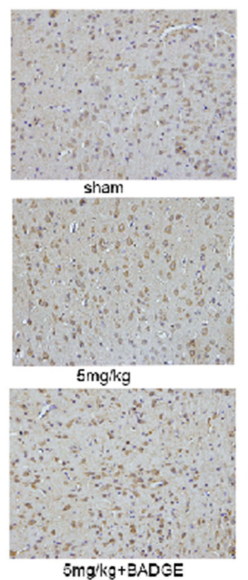

$5 m g / k g+B A D G E$
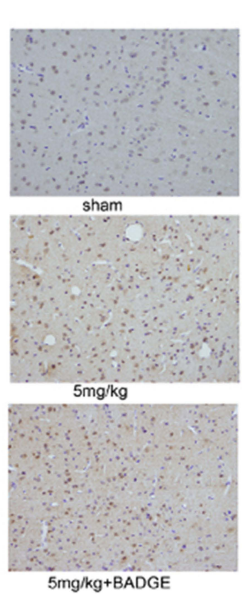

MMP2
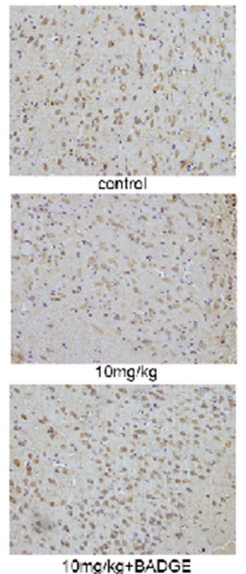

MMP9
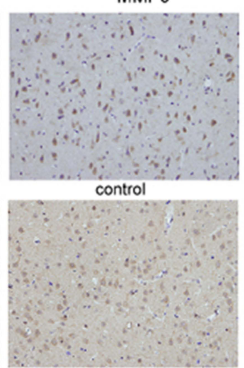

$10 \mathrm{mg} / \mathrm{kg}$

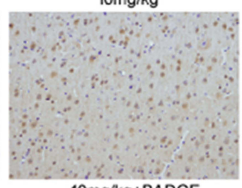

$10 \mathrm{mg} / \mathrm{kg}+\mathrm{BADGE}$
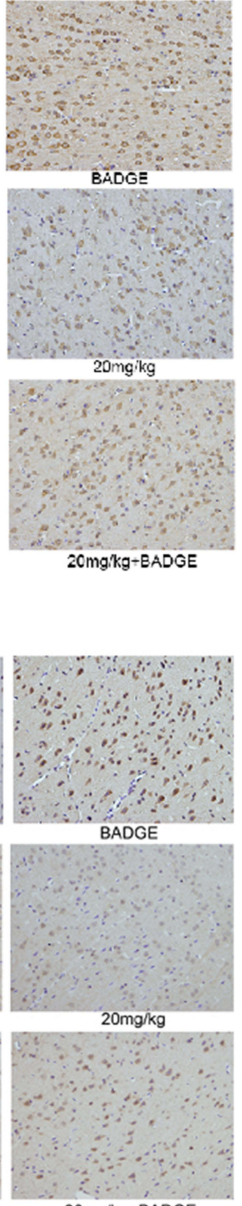

B
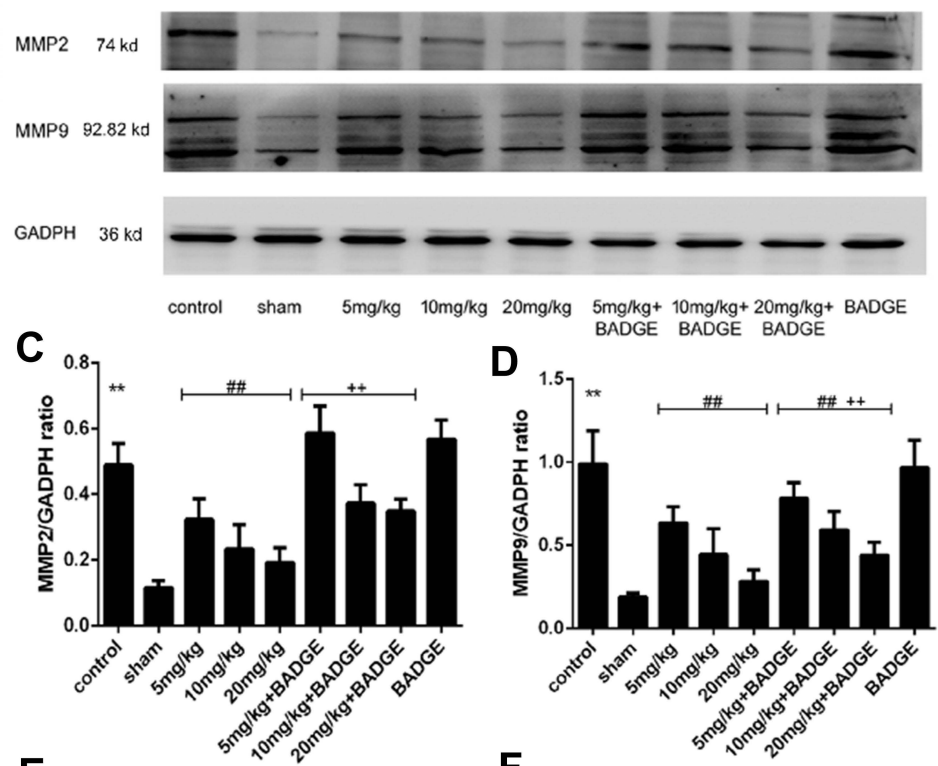

E

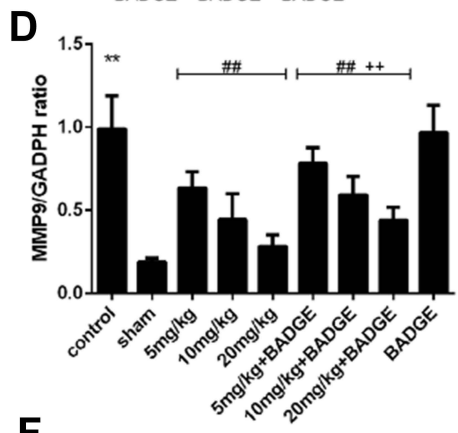

$\mathbf{F}$

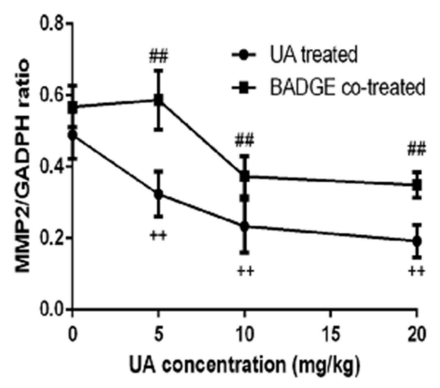

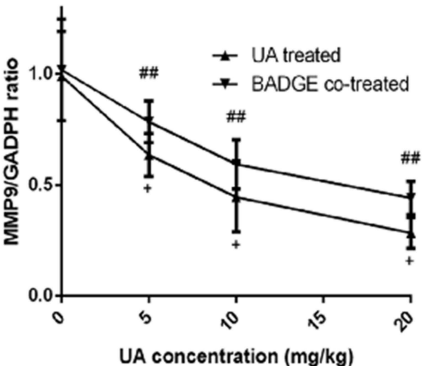

Figure 4 Effects of UA on MMP2 and MMP9.

Notes: Cerebral ischemia and reperfusion increased the protein levels of MMP2 and MMP9 $(* * P<0.01)$. UA treatment $(5,10$, or $20 \mathrm{mg} / \mathrm{kg})$ decreased the protein levels of MMP2 and MMP9 and the activity level of MMP9 in a dose-dependent manner ( $\left.{ }^{\#} P<0.01\right)$. BADGE completely abolished the UA-induced reduction in the MMP2 protein level $\left({ }^{++} P<0.01\right)$ and partly abolished the reduction in the MMP9 level $\left({ }^{\#} P<0.01\right)$. (A) The protein expression of MMP2 and MMP9 was confirmed via immunochemical staining. (B) The protein expression of MMP2 and MMP9 was measured by Western blotting 400× magnification. We distinguished the active form of MMP9 from its inactive form. (C and D) The target protein bands were analyzed via densitometry and normalized to the GA DPH levels. (E and F) The MMP/GA DPH band intensity ratio decreased with increasing UA concentrations, and this effect on MMPs significantly differed between the UA-treated groups. Mean values \pm standard error of the mean for six rats per group $\left({ }^{* * P} P<0.0\right.$ I: versus sham; ${ }^{\#} P<0.0$ I: versus control; ${ }^{++} P<0.01$ : versus UA-treated; ${ }^{+} P<0.05$ : versus UA-treated).

Abbreviations: UA, ursolic acid; BADGE, bisphenol A diglycidyl ether. 


\section{Publish your work in this journal}

Drug Design, Development and Therapy is an international, peerreviewed open-access journal that spans the spectrum of drug design and development through to clinical applications. Clinical outcomes, patient safety, and programs for the development and effective, safe, and sustained use of medicines are a feature of the journal, which has also

been accepted for indexing on PubMed Central. The manuscript management system is completely online and includes a very quick and fair peer-review system, which is all easy to use. Visit http://www. dovepress.com/testimonials.php to read real quotes from published authors.

Submit your manuscript here: https://www.dovepress.com/drug-design-development-and-therapy-journal 